\title{
ALQURUN TEACHING MODEL-BASED TRIGONOMETRY TEACHING MATERIAL
}

\author{
Rizki Wahyu Yunian Putra ${ }^{*}$, Suherman ${ }^{2}$, Bambang Sri Anggoro³ ${ }^{3}$ Aan Subhan \\ Pamungkas $^{4}$ \\ 1,2,3 Department of Mathematics Education, Universitas Islam Negeri Raden Intan Lampung, Indonesia \\ ${ }^{4}$ Department of Mathematics Education, Universitas Sultan Ageng Tirtayasa, Indonesia
}

*Corresponding author: rizkiwahyuyp@ radenintan.ac.id

\begin{tabular}{|c|c|}
\hline Article Info & ABSTRACT \\
\hline Article history: & \multirow{6}{*}{$\begin{array}{l}\text { Learning in the industrial era } 4.0 \text { requires innovation in the } \\
\text { development of teaching materials. The purpose of this research is } \\
\text { to develop a valid and attractive Alqurun Teaching Model (ATM) } \\
\text { teaching material for learning trigonometry. This research was a } \\
\text { development research using the ADDIE (Analysis, Design, } \\
\text { Development, Implementation, and Evaluation) model. Data were } \\
\text { collected using a questionnaire. The small group test was conducted } \\
\text { by } 9 \text { respondents and the large group test was carried out by } 12 \\
\text { respondents. The results showed that based on material experts, this } \\
\text { teaching material received a feasibility score of } 4.06,4.78 \text { from } \\
\text { media experts, and } 4.19 \text { from linguists, all of which indicated that } \\
\text { this teaching material was in the very feasible category. The results } \\
\text { of the small and large group tests showed a score of } 3.36 \text { and } 4.21 \text {, } \\
\text { meaning that this teaching material was very interesting. So, it can } \\
\text { be concluded that this teaching material can be used in learning } \\
\text { trigonometry. }\end{array}$} \\
\hline Received: November 9, 2019 & \\
\hline Acc & \\
\hline Published: July 31 & \\
\hline Keywords: & \\
\hline $\begin{array}{l}\text { Alqurun teaching model } \\
\text { Learning material } \\
\text { Trigonometry }\end{array}$ & \\
\hline
\end{tabular}

\begin{tabular}{|c|c|}
\hline \multicolumn{2}{|c|}{$\begin{array}{c}\text { BAHAN AJAR TRIGONOMETRI BERBASIS ALQURUN } \\
\text { TEACHING MODEL }\end{array}$} \\
\hline & ABSTRAK \\
\hline $\begin{array}{l}\text { Kata Kunci: } \\
\text { Alqurun teaching model } \\
\text { Bahan ajar } \\
\text { Trigonometri }\end{array}$ & $\begin{array}{l}\text { Pembelajaran di era industri } 4.0 \text { perlu adanya inovasi } \\
\text { pengembangan bahan ajar. Tujuan penelitian ini yaitu } \\
\text { mengembangkan bahan ajar Alqurun Teaching Model (ATM) yang } \\
\text { valid dan menarik terhadap pembelajaran trigonometri di era } \\
\text { industri 4.0. Penelitian ini merupakan penelitian pengembangan } \\
\text { ADDIE (Analysis, Design, Development, Implementation, and } \\
\text { Evaluation). Instrumen pengumpulan data adalah angket. Uji } \\
\text { kelompok kecil dilakukan oleh } 9 \text { responden dan uji kelompok besar } \\
\text { dilakukan oleh } 12 \text { responden. Hasil penelitian menunjukkan bahwa } \\
\text { berdasarkan ahli materi, bahan ajar ini mendapat skor kelayakan } \\
\text { 4,06, dan ahli media memberikan skor } 4,78 \text {, dan } 4,19 \text { dari ahli } \\
\text { bahasa, semuanya menunjukkan bahwa bahan ajar ini berada pada } \\
\text { kategori sangat layak. Hasil uji kelompok kecil dan besar } \\
\text { menunjukkan skor } 3,36 \text { dan } 4,21 \text {, artinya, bahan ajar ini sangat } \\
\text { menarik. Sehingga, dapat disimpulkan bahwa bahan ajar ini dapat } \\
\text { digunakan dalam pembelajaran trigonometri. }\end{array}$ \\
\hline
\end{tabular}




\section{INTRODUCTION}

Developments in mathematics learning in the digital era need to be followed up. Learning shouldn't just be limited to practicing skills and memorizing [1]-[3], but through learning, students must be able to understand the concept well and be able to apply it to solve a problem [4]-[6]. Learning in the digital age must be presented with a pleasant learning atmosphere that can attract students' interest [7], hence, teaching materials are needed to support multidirectional learning [8]-[10]. Teaching materials are important in learning to create a pleasant learning atmosphere so that information will be well received by students [11], [12] and learning will get good results [13]. Apart from being a curriculum requirement [14]-[16], Teaching materials are also needed to make it easier for students to understand learning topics and to help students learn independently [17]-[19].

Several studies have revealed that there were still few teachers and lecturers who develop teaching materials by themselves [20]-[22], thus, learning only went in one direction and students tend to be passive [23]-[25], less motivated to learn [26], [27], not accustomed to investigating and analyzing objects [28]-[30], students' synthesis thinking process that became less meaningful [31]-[33], and are not used to solving problems in new ways, especially on trigonometry [34]-[36]. This problem needs to be resolved, so that students can have new and meaningful experiences in learning. As a solution, it is necessary to develop teaching materials that can facilitate these activities. In this study, researchers developed teaching materials based on the Qur'anic Teaching Model (ATM). ATM was chosen because students need to learn to construct new ideas in various situations, then learn to review a problem, as needed to learn trigonometry topics. Based on the researcher's analysis, it is known that the use of teaching materials as a learning resource is very important. In order for the learning process to run well and interestingly, the researchers developed the ALQURUN Teaching Model-based trigonometry teaching material.

Previous research has shown that the development of the Al-qurun Teaching Model has succeeded in being a solution in improving learning outcomes on the topic of Pythagorean [40], other research also showed that students became more motivated in learning mathematical concepts after learning with the Al-Qur'an Teaching Model [42], other research have also stated that ATM makes students accustomed to finding mathematical concepts [43].

If previous researches have focused on the application of the Alqurun teaching model in learning, in this study we developed teaching materials based on the Alquru teaching model on trigonometric material. So that the purpose of this study is to determine the feasibility and response of students to ATM-based trigonometry teaching materials.

\section{METHOD}

The method used in this study is Research and Development with the ADDIE development model (Analysis, Design, Development, Implementation, Evaluation) [44]. Figure 1 below illustrates the ADDIE development model design.

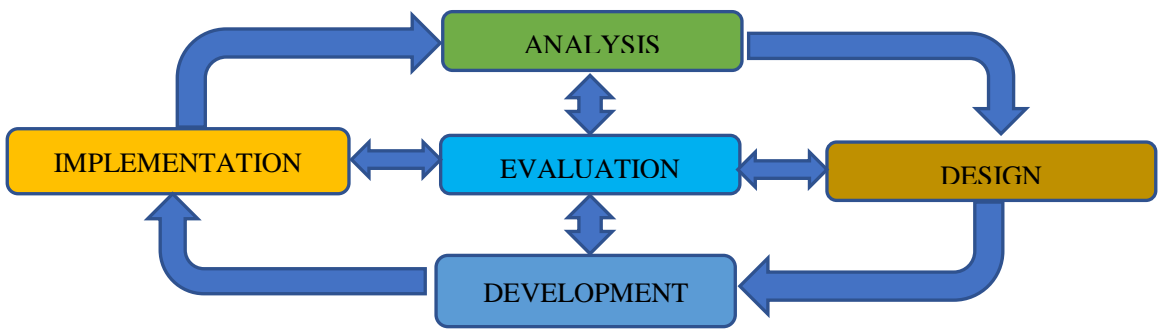

Figure 1. ADDIE Development Model Design

220 Indonesian Journal of Science and Mathematics Education ( I J S M E ) 
At analysis stage, we conduct a needs analysis of teaching materials for students and lecturers, curriculum analysis, and analysis of student characteristics. At design stage, we design teaching material. At development stage, a conceptual framework for the application of new teaching material was drawn up. The initial product was then tested for the feasibility of the material, media, and language. The expert validation assessment score consists of five categories, i.e. Very Good (VG) with a score of 5, Good (G) with a score of 4, Fair (F) with a score of 3, Poor (P) with a score of 2, and Very Poor (VP) with a score of 1 .

The validation results were analyzed using descriptive quantitative. The feasibility interpretation test is shown in table 1 below [22]:

Table 1. Interpretation of Feasibility

\begin{tabular}{cll}
\hline Score & \multicolumn{1}{c}{ Criteria } & \multicolumn{1}{c}{ Conclusion } \\
\hline $3,26<\bar{x} \leq 4,00$ & Very Good/ Valid & No need revision \\
$2,51<\bar{x} \leq 3,26$ & Good/ Quite valid & Partial revision \\
$1,76<\bar{x} \leq 2,51$ & Poor/ Not valid & $\begin{array}{l}\text { Partial revision \& need for re-assessment of the } \\
\text { material }\end{array}$ \\
& & Overall revision \\
\hline
\end{tabular}

Implementation stage was carried out to determine the response of students to the teaching materials that have been developed. Evaluation in the last stage was evaluation of student responses based on the results of the questionnaire that has been given. The technique of analyzing product validity data was validation of material and media experts using a likert scale, with a score of 4 (very good), 3 (good), 2 (poor), and 1 (very poor).

\section{RESULTS AND DISCUSSION}

Based on the research that has been done, the results of the research analysis are:

\subsection{Analysis Stage}

We conducted an analysis of the students' lack of interest in learning mathematics. One of the biggest contributing factors was due to monotonous learning, which results in low trigonometric learning outcomes. In the 2013 curriculum, learning must be carried out with a scientific approach, meaning that students must learn to find concepts through learning activities. To increase student interest, teaching materials developed based on student character are needed.

\subsection{Design Stage}

The design of teaching materials involved designing instruments. The difference between ATM-based teaching material and teaching materials commonly used in schools and universities is that this teaching material have learning steps based on ATM syntax. So that, it became a more interesting and challenging teaching material.

\subsection{Development Stage}

The teaching materials made at this stage were in accordance with the design at the design stage. The stages of Alqurun Teaching Model (ATM) learning in this teaching material are illustrated in Figure 2. 

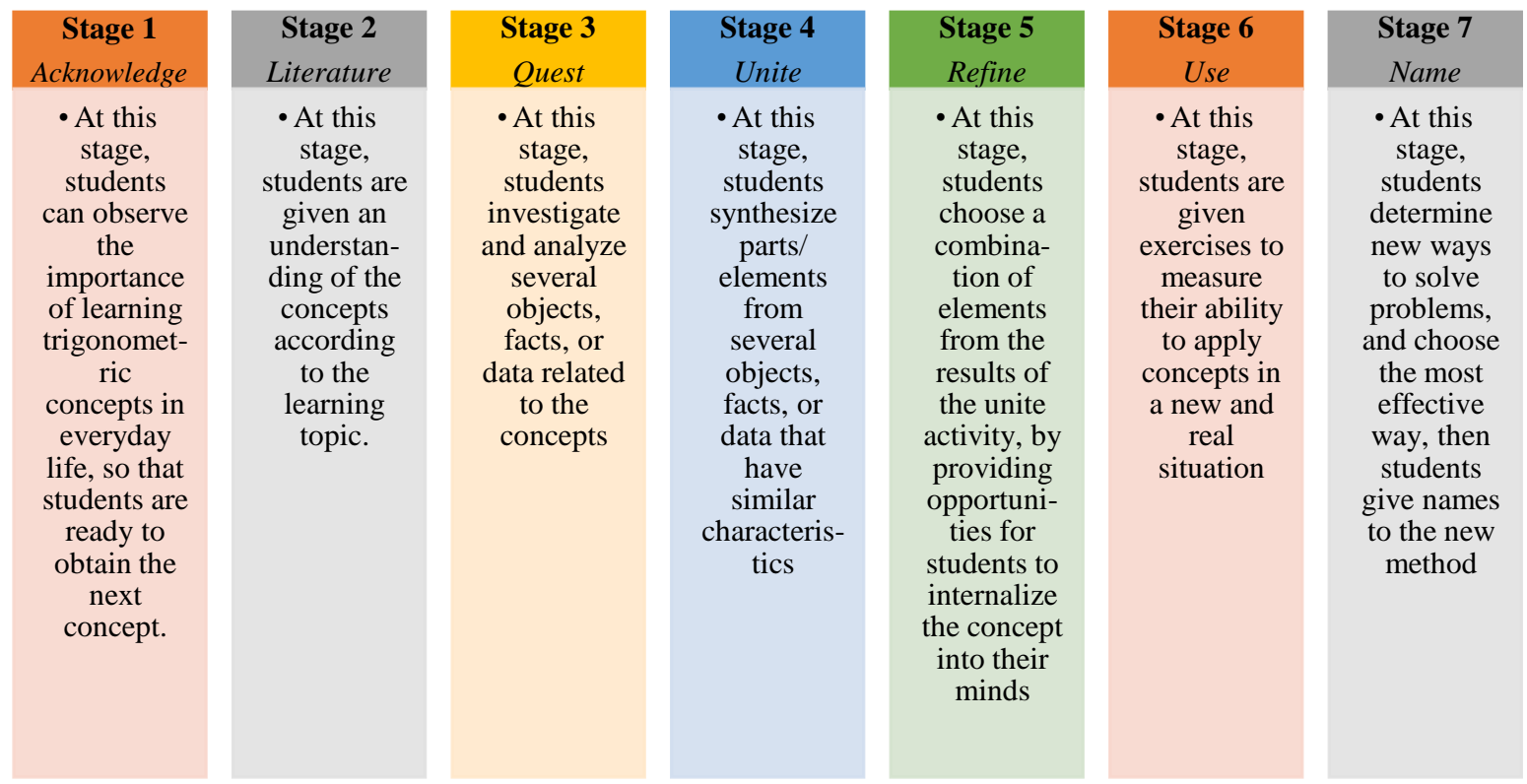

Figure 2. Design of Teaching Material

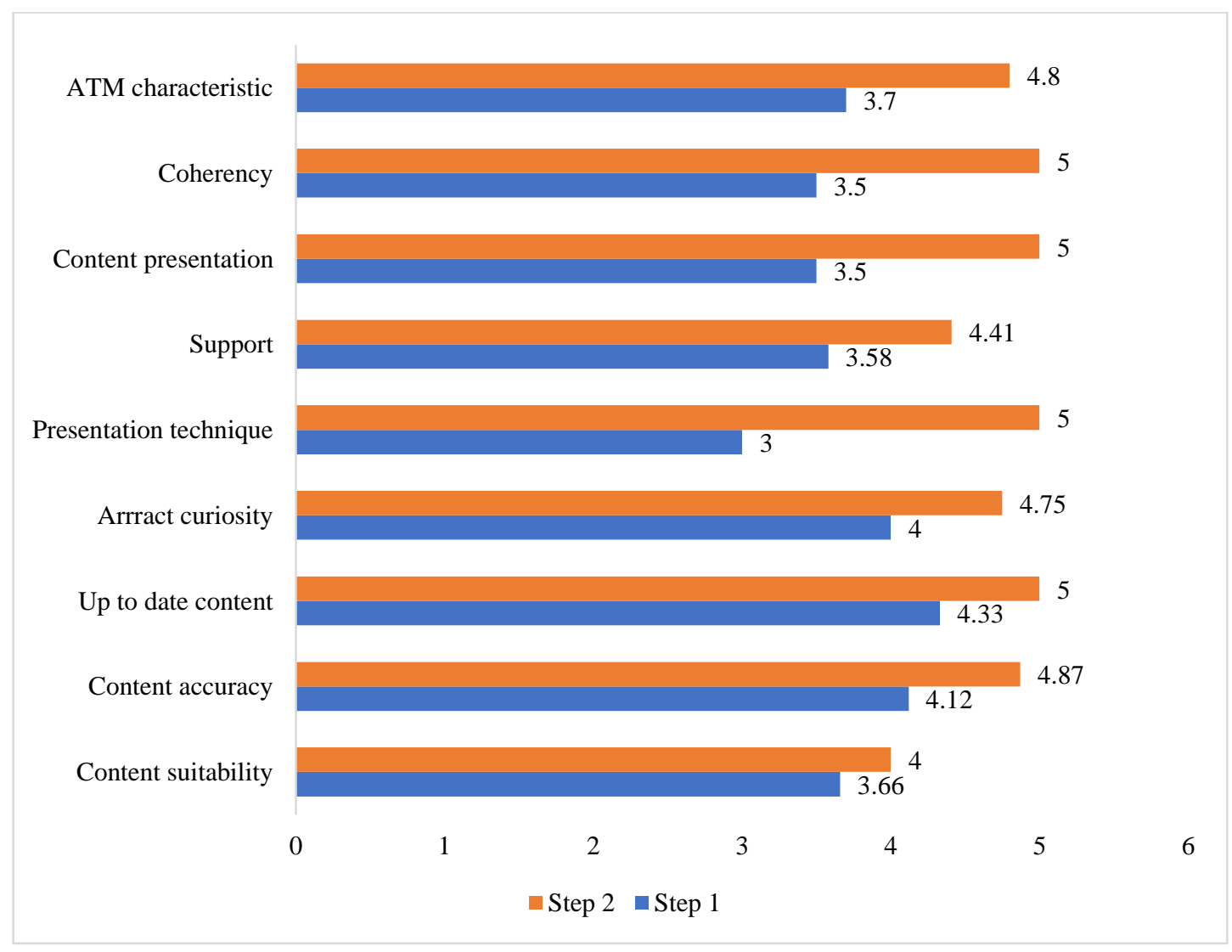

Figure 3. Material Expert Validation Results 


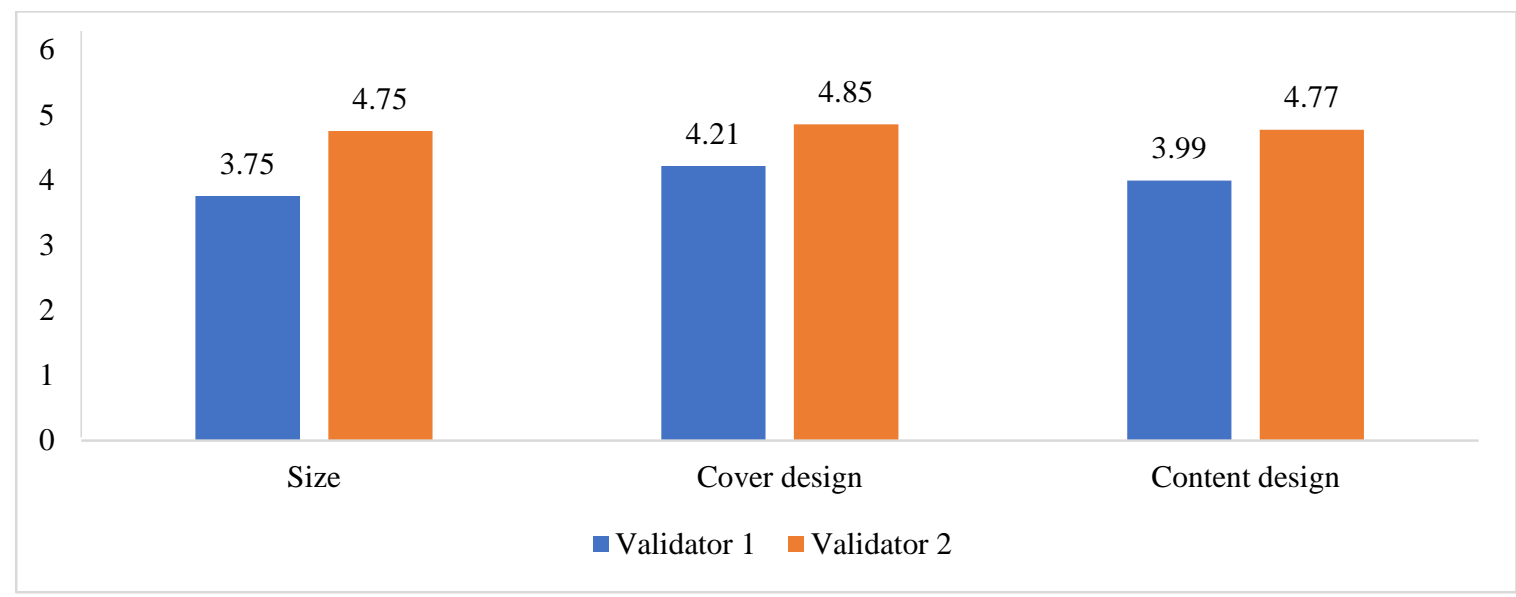

Figure 4. Media Expert Validation Results

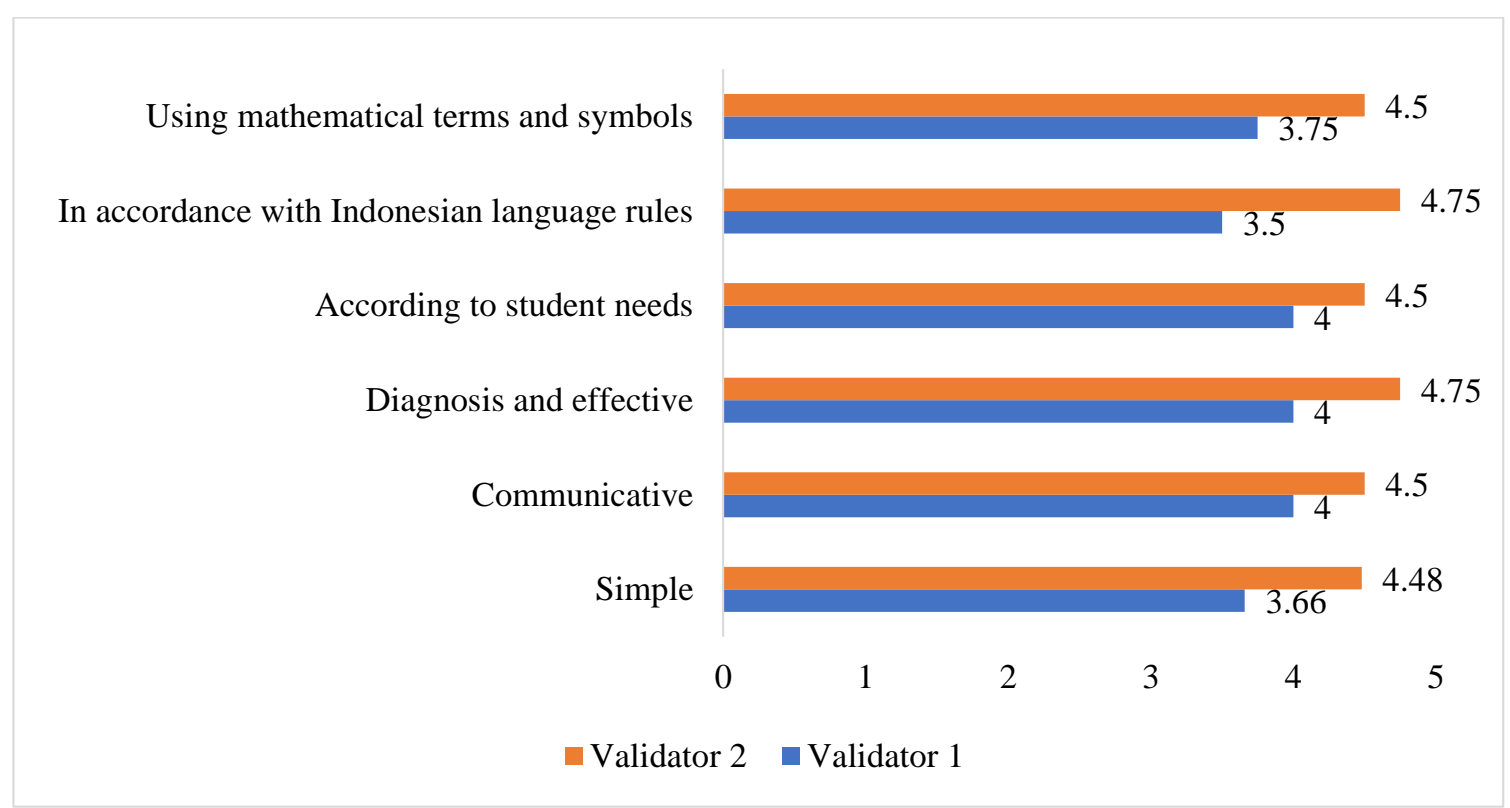

Figure 5. Linguist Validation Results

\subsection{Implementation Stage}

This product attractiveness test was carried out by small-scale trial and large-scale trial. The small scale trial was carried out by involving 9 respondents, while the large-scale trial involved 27 respondents.

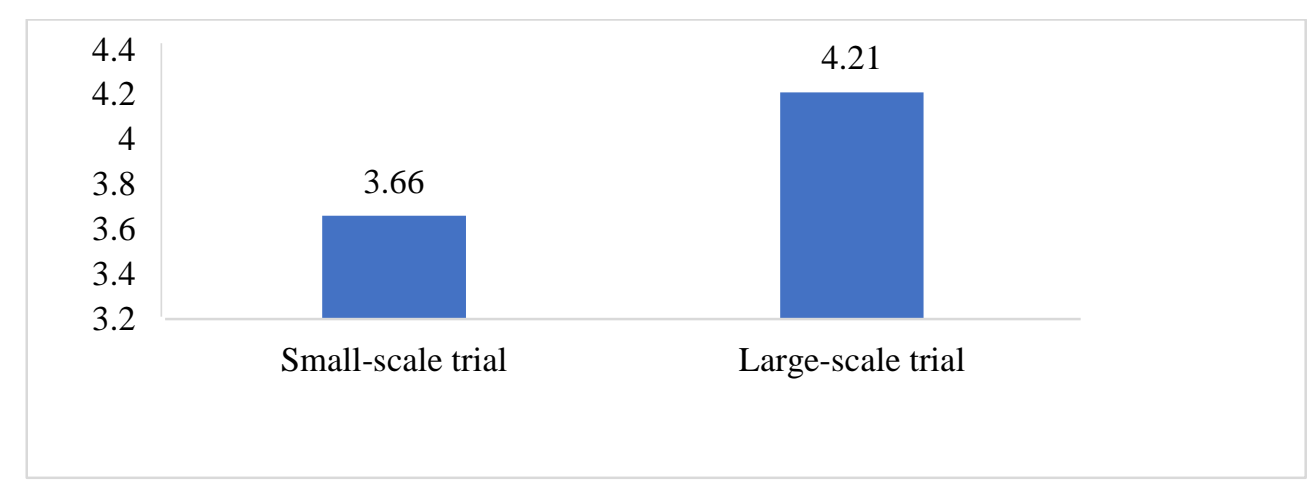

Figure 6. Product Trial Results 
The development of teaching materials based on the Alqurun Teaching Model (ATM) was carried out very carefully and went through various evaluation processes at each stage. This evaluation was carried out to observe and record all the processes that have been done at each stage. Thus, the result was a feasible and interesting teaching material to be used as a learning tool in the topic of trigonometry. This result is in line with the result of previous research which stated that ATM teaching material can be a solution in overcoming learning problems by attracting student learning interest [40], because this teaching material was feasible and interesting [42], [43]. The distinctive feature of Alqurun Teaching Model-based teaching material was that learning activities in teaching material were enriched with work steps based on ATM steps [41], [42]. So as to make students more motivated in learning trigonometric concept [45].

\section{CONCLUSION}

Based on data analysis, it can be concluded that the Alqurun Teaching Model (ATM) -based Trigonometric Teaching Material was declared valid by material experts, media experts and linguists. The material expert validation gave a score of 4.06 , the media expert gave a score of 4.78 , and the linguist gave a score of 4.19 , all of which were in the very feasible category. Small and large group tests showed a score of 3.36 and 4.21 with very interesting categories. This research needs to be developed for other learning topics, so that it becomes a solution for other learning topics.

\section{ACKNOWLEDGMENT}

Thank you to the Institute of Research and Community Service (Lembaga Penelitian dan Pengabdian Masyarakat/ LP2M), UIN Raden Intan Lampung, who have provided financial support for this research.

\section{REFERENCES}

[1] A. Fadillah, "Pengaruh pembelajaran problem solving terhadap kemampuan berpikir kreatif matematis siswa," FIBONACCI J. Pendidik. Mat. Dan Mat., vol. 2, no. 1, pp. $1-8,2016$.

[2] M. Masjudin, "Pembelajaran Kooperatif Investigatif Untuk Meningkatkan Pemahaman Siswa Materi Barisan Dan Deret," J. Edukasi Mat. Dan Sains, vol. 4, no. 2, pp. 76-84, 2017.

[3] G. Rahayuni, "Hubungan keterampilan berpikir kritis dan literasi sains pada pembelajaran IPA terpadu dengan model PBM dan STM," J. Penelit. Dan Pembelajaran IPA, vol. 2, no. 2, pp. 131-146, 2016.

[4] A. Muhson, "Peningkatan minat belajar dan pemahaman mahasiswa melalui penerapan problem-based learning," J. Kependidikan Penelit. Inov. Pembelajaran, vol. 39, no. 2, 2009.

[5] A. S. Situmorang, "Desain Model Pembelajaran Based Learning Dalam Peningkatan Kemampuan Konsep Mahasiswa Semester Tiga Jurusan Pendidikan Matematika FKIP-UHN Medan,” J. SULUH Pendidik., 2014.

[6] S. Suherman, "Kreativitas Siswa Dalam Memecahkan Masalah Matematika Materi Pola Bilangan Dengan Pendekatan Matematika Realistik (PMR)," Al-Jabar J. Pendidik. Mat., vol. 6, no. 1, pp. 81-90, 2015.

[7] R. Sundayana, "Kaitan antara gaya belajar, kemandirian belajar, dan kemampuan pemecahan masalah siswa SMP dalam pelajaran matematika," Mosharafa J. Pendidik. Mat., vol. 5, no. 2, pp. 75-84, 2016. 
[8] K. Hutagaol, "Pembelajaran kontekstual untuk meningkatkan kemampuan representasi matematis siswa sekolah menengah pertama," Infin. J., vol. 2, no. 1, pp. 85-99, 2013.

[9] F. Rizki and R. Widyastuti, "Penggunaan Aplikasi Microsoft Mathematics untuk Pengembangan Bahan Ajar matematika Siswa," Desimal J. Mat., vol. 2, no. 1, pp. 17, 2019.

[10] K. Swandhana, M. Churiyah, and L. Juariyah, "Meningkatkan Kemandirian Belajar dan Hasil Belajar Siswa melalui Pengembangan Modul Administrasi Kepegawaian Berbasis Strategi Pembelajaran Inkuiri Terbimbing," JPBM J. Pendidik. Bisnis Dan Manaj., vol. 2, no. 3, pp. 161-169, 2016.

[11] T. Guasch, I. Alvarez, and A. Espasa, "University teacher competencies in a virtual teaching/learning environment: Analysis of a teacher training experience," Teach. Teach. Educ., vol. 26, no. 2, pp. 199-206, 2010.

[12] K. C. Williams and C. C. Williams, "Five key ingredients for improving student motivation," Res. High. Educ. J., vol. 12, p. 1, 2011.

[13] A. Machin, "Implementasi pendekatan saintifik, penanaman karakter dan konservasi pada pembelajaran materi pertumbuhan," J. Pendidik. IPA Indones., vol. 3, no. 1, 2014.

[14] J.-W. Park, "Developing the Format and Samples of Teaching Materials for Scientific Creativity in the Ordinary Science Curriculum-Including TeachersPractice and Reflection," J. Korean Assoc. Sci. Educ., vol. 32, no. 3, pp. 446-466, 2012.

[15] S. F. Shawer, "Classroom-level curriculum development: EFL teachers as curriculum-developers, curriculum-makers and curriculum-transmitters," Teach. Teach. Educ., vol. 26, no. 2, pp. 173-184, 2010.

[16] I. Thomas, "Sustainability in tertiary curricula: what is stopping it happening?," Int. J. Sustain. High. Educ., vol. 5, no. 1, pp. 33-47, 2004.

[17] D. Carless and D. Boud, "The development of student feedback literacy: enabling uptake of feedback," Assess. Eval. High. Educ., vol. 43, no. 8, pp. 1315-1325, 2018.

[18] M. Ebner, C. Lienhardt, M. Rohs, and I. Meyer, "Microblogs in Higher EducationA chance to facilitate informal and process-oriented learning?," Comput. Educ., vol. 55, no. 1, pp. 92-100, 2010.

[19] N. Indriani, A. S. Pamungkas, and T. P. Alamsyah, "Pengembangan Lembar Aktivitas Matematika Berorientasi Pendekatan Saintifik," Desimal J. Mat., vol. 2, no. 2, pp. 105-117, 2019.

[20] M. Jalil, "Pengembangan Pembelajaran Model Discovery Learning berbantuan tips powerpoint interaktif pada materi interaksi makhluk hidup dengan lingkungan," Refleksi Edukatika J. Ilm. Kependidikan, vol. 6, no. 2, 2016.

[21] H. Rodiawati and K. Komarudin, "Pengembangan e-learning melalui modul interaktif berbasis learning content development system," J. Tatsqif, vol. 16, no. 2, pp. 172-185, 2018.

[22] T. N. Utami, A. Jatmiko, and S. Suherman, "Pengembangan Modul Matematika dengan Pendekatan Science, Technology, Engineering, And Mathematics (STEM) pada Materi Segiempat," Desimal J. Mat., vol. 1, no. 2, pp. 165-172, 2018, doi: https://doi.org/10.24042/djm.v1i2.2388.

[23] B. S. Anggoro, H. Efendi, and S. Suherman, "The Impact Of EthnomathematicsBased Probing-Prompting Learning Method On Class IX SMP Negeri 2 Way Tenong Students'mathematical Communication Skills Year 2016/2017," Asian J. Curr. Res., pp. 1-8, 2019. 
[24] M. Correa, "Flipping the foreign language classroom and critical pedagogies: a (new) old trend," High. Educ. Future, vol. 2, no. 2, pp. 114-125, 2015.

[25] P. K. Sharma, "Combining diverse pedagogical tools for effective teaching of general biology to a large class comprising of first year science and engineering undergraduates," Educ. Quest- Int. J. Educ. Appl. Soc. Sci., vol. 8, no. 3, pp. 517524, 2017.

[26] S. M. Hölter, M. Kallnik, W. Wurst, G. Marsicano, B. Lutz, and C. T. Wotjak, "Cannabinoid CB1 receptor is dispensable for memory extinction in an appetitivelymotivated learning task," Eur. J. Pharmacol., vol. 510, no. 1-2, pp. 69-74, 2005.

[27] L. Ku, H. Dittmar, and R. Banerjee, "Are materialistic teenagers less motivated to learn? Cross-sectional and longitudinal evidence from the United Kingdom and Hong Kong.," J. Educ. Psychol., vol. 104, no. 1, p. 74, 2012.

[28] S. Isnaeni, L. Fajriyah, E. S. Risky, R. Purwasih, and W. Hidayat, "Analisis kemampuan penalaran matematis dan kemandirian belajar siswa SMP pada materi persamaan garis lurus," J. Medives J. Math. Educ. IKIP Veteran Semarang, vol. 2, no. 1, pp. 107-116, 2018.

[29] N. Netriwati, "Penerapan Taksonomi Bloom Revisi untuk Meningkatkan Kemampuan Pemahaman Konsep Matematis," Desimal J. Mat., vol. 1, no. 3, pp. 347-352, 2018.

[30] R. D. Purwanti, D. D. Pratiwi, and A. Rinaldi, "Pengaruh Pembelajaran Berbatuan Geogebra terhadap Pemahaman Konsep Matematis ditinjau dari Gaya Kognitif," AlJabar J. Pendidik. Mat., vol. 7, no. 1, pp. 115-122, 2016.

[31] S. Andriani, H. Suyitno, I. Junaidi, S. Suherman, M. Mujib, and M. Mardiyah, "The Application of Differential Equation of Verhulst Population Model on Estimation of Bandar Lampung Population," in Journal of Physics: Conference Series, 2019, vol. 1155, p. 012017.

[32] S. Hartinah et al., "Probing-Prompting Based On Ethnomathematics Learning Model: The Effect On Mathematical Communication Skill," J. Educ. Gift. Young Sci., vol. 7, no. 4, pp. 799-814, 2019.

[33] U. N. Hasanah, A. Thahir, K. Komarudin, and R. Rahmahwaty, "MURDER Learning and Self Efficacy Models: Impact on Mathematical Reflective Thingking Ability," $J$. Educ. Gift. Young Sci., vol. 7, no. 4, pp. 1123-1135, 2019.

[34] J. L. Docktor and J. P. Mestre, "Synthesis of discipline-based education research in physics," Phys. Rev. Spec. Top.-Phys. Educ. Res., vol. 10, no. 2, p. 020119, 2014.

[35] M. A. S. Parrot and K. E. Leong, "Impact of using graphing calculator in problem solving," Int. Electron. J. Math. Educ., vol. 13, no. 3, pp. 139-148, 2018.

[36] E. Retnowati and S. R. Maulidya, "Designs of goal-free problems for trigonometry learning," in Journal of Physics: Conference Series, 2018, vol. 983, p. 012125.

[37] H. Holidun, R. Masykur, S. Suherman, and F. G. Putra, "Kemampuan Pemecahan Masalah Matematis Kelompok Matematika Ilmu Alam dan Ilmu-Ilmu Sosial," Desimal J. Mat., vol. 1, no. 1, pp. 29-37, 2018.

[38] S. Mawaddah and H. Anisah, "Kemampuan pemecahan masalah matematis siswa pada pembelajaran matematika dengan menggunakag) di smpn model pembelajaran generatif (generative learning) di smp," EDU-MAT J. Pendidik. Mat., vol. 3, no. 2, 2015.

[39] R. W. Y. Putra, J. Fakhri, and D. Fitriani, “The Development of Teaching Materials Gamification-Based Problem Solving on the Material in Terms of Four," Int. J. Trends Math. Educ. Res., vol. 2, no. 2, pp. 58-63, 2019. 
[40] Y. B. Putri, S. Sutiarso, and U. Rosidin, "Pengembangan Bahan Ajar Berbasis Alqurun Teaching Model pada Materi Teorema Phytagoras," J. Pendidik. Mat. Unila, vol. 5, no. 3, 2017.

[41] S. Wahyuningsih, S. Sutiarso, and W. Widyastuti, "Efektivitas Alqurun Teaching Model ditinjau dari Kemampuan Pemahaman Konsep Matematis Siswa," J. Pendidik. Mat. Unila, vol. 7, no. 2, 2019.

[42] Y. Puspitasari, S. Sutiarso, and S. Suharsono, "Pengembangan LKPD Berbasis Alqurun Teaching Model untuk Meningkatkan Pemahaman Konsep Matematika," $J$. Pendidik. Mat. Unila, vol. 5, no. 10, 2017.

[43] T. Oktiania, S. Sutiarso, and U. Rosidin, "Pengembangan Bahan Ajar Berbasis ALQURUN Teaching Model (ATM) Pada Konsep Materi Lingkaran," J. Pendidik. Mat. Unila, vol. 5, no. 5, 2017.

[44] K. Kruse, "Introduction to instructional design and the ADDIE model," Retrieved January, vol. 26, p. 2005, 2002.

[45] Y. B. Putri, S. Sutiarso, and U. Rosidin, "Pengembangan Bahan Ajar Berbasis Alqurun Teaching Model pada Materi Teorema Phytagoras," J. Pendidik. Mat. Unila, vol. 5, no. 3, 2017. 